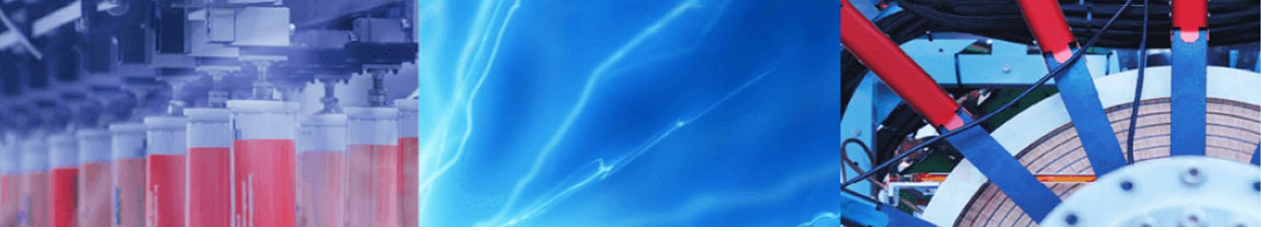

Research Article

\title{
Gold@mesoporous silica nanocarriers for the effective delivery of antibiotics and by-passing of $\beta$-lactam resistance
}

\author{
Gonçalo A. Marcelo ${ }^{1} \cdot$ Maria Paula Duarte ${ }^{2}$ Elisabete Oliveira ${ }^{1,3}$
}

Received: 13 February 2020 / Accepted: 9 June 2020 / Published online: 8 July 2020

(c) Springer Nature Switzerland AG 2020

\begin{abstract}
Current antibiotics effectiveness relies on higher doses and administration frequency, which are responsible for the growth of antimicrobial resistance (AMR). AMR is one of the major threatening issues of the century with last-line antibiotics already failing. To overcome such problems associated with bacterial infections, nanoparticles combined with antibiotics emerged as a promising strategy. In this work, nanocarriers comprising of gold-silica core-shell mesoporous nanoparticles (Au@MNs) and silica mesoporous nanoparticles (MNs) were synthesized, loaded with amoxicillin (Amox) and ofloxacin and investigated regarding its antibacterial activity towards S. aureus, methicillin-resistant S. aureus (MRSA), $E$. coli and $P$. aeruginosa. Both nanocarriers showed a beneficial role in the effective delivery of amoxicillin against MRSA and the well-known $\beta$-lactam resistant P. aeruginosa. Reductions of 10-fold (Amox@MNs) and 20-fold (Amox@Au@MNs) in the amount of antibiotic to treat P. aeruginosa; and a reduction of 20-fold (Amox@MNs) towards MRSA allied to a full reversion of resistance, strongly supports the promising potential of these nanocarriers to tackle antibiotics resistance.
\end{abstract}

Keywords Mesoporous silica nanoparticles · Amoxicillin · Ofloxacin · Antimicrobial resistance $\cdot$ Bacteria · Gold nanoparticles

\section{Introduction}

The inappropriate administration of antibiotics and their relative non-specificity are responsible for bacterial infections treatment's ineffectiveness and for the growth of antimicrobial resistance $[1,2]$. Recent studies presented by the European Food Safety Authority (EFSA) and by the European Centre for Disease Prevention and Control (ECDC) conducted in the 28 European member states revealed an increased resistance to antibiotics in the Salmonella, Escherichia coli and Staphylococcus aureus bacteria strains [2, 3]. As a consequence, current antibiotics effectiveness relies on higher drug doses and administration frequency, which in turn favour the emergence of new resistant bacteria [3]. To overcome this issue, the production of novel antibiotics has been proposed as a solution. However, with time these drugs will cease to be effective, as well. The resolution should focus then on the increase of the durability and effectiveness of existing drugs and not in the design of new ones [3].

The implementation of nanoparticles as antibacterial agents appears to be a very promising strategy to overcome such problems associated with bacterial infections. Toxicity reduction, drug solubility enhancement,

Electronic supplementary material The online version of this article (https://doi.org/10.1007/s42452-020-3023-6) contains supplementary material, which is available to authorized users.

$\triangle$ Maria Paula Duarte, mpcd@fct.unl.pt; $₫$ Elisabete Oliveira, ej.oliveira@fct.unl.pt | ${ }^{1}$ BIOSCOPE Group, LAQV@REQUIMTE, NOVA School of Science and Technology, NOVA University of Lisbon, 2829-516 Caparica, Portugal. ${ }^{2}$ MEtRICs/DCTB, NOVA School of Science and Technology, NOVA University of Lisbon, 2829-516 Caparica, Portugal. ${ }^{3}$ PROTEOMASS Scientific Society, Rua dos Inventores, Madan Parque, 2825-182 Caparica, Portugal. 
controlled release of multiple drugs, lower antibiotic dosage, resistance overcoming and lower costs are some of the advantages reported by the use of the nanomaterials, compared with conventional antibiotics $[4,5]$.

Regarding antibacterial nanomaterials, inorganic nanoparticles containing silver, gold, copper oxide, titanium oxide, and cerium oxide nanoparticles have been found to have potent antibacterial effects [6-9]. It has been proposed that these materials can exert antibacterial activity through multiple modes of action, such as metal ions release, non-oxidative and oxidative stress, leading to multiple gene mutations in the bacterial cell and consequently inhibiting bacteria from acquiring resistance against nanoparticles [10].

Among all nanomaterials, mesoporous silica nanoparticles (MNs), are very promising for pharmaceutical use, mainly due to their multiple design options, providing different strategies to combat bacterial infections [11]. MNs have a high surface area and pore volume with a large loading capacity to combat bacterial infection in all stages (prevention, detection and treatment). Several studies showed that loading antibiotics onto MNs induces an improvement in the effectiveness of the drug $[3,12,13]$. Moreover, the combination of MNs with other metals (copper, zinc, silver, gold) can bring an added value in bacterial eradication [14, 15].

As an example, Zink et al. [16] reported the antibacterial effect of silver nanocrystal into MNs against $E$. coli and Bacillus anthracis, showing efficiency against $B$. anthracis in the smallest tested concentration $(20 \mu \mathrm{g} / \mathrm{mL})$. A more sophisticated system was published by Zhou et al. [17] where chlorhexidine (CHX) was loaded into silver@MNs and tested against $S$. aureus and E. coli. In both bacteria, the CHX@silver@MNs system showed a synergistic bactericidal effect higher than $\mathrm{AgNO}_{3}$ and $\mathrm{CHX}$ separately, with a minimum inhibitory concentration (MIC) and minimum bactericidal concentration (MBC) of $25 \mu \mathrm{g} / \mathrm{mL}$ and $12.5 \mu \mathrm{g} /$ $\mathrm{mL}$ for S. aureus and E. coli, respectively.

Silver core-mesoporous silica nanoparticles loaded with ofloxacin (AgMNs@oflox) were also tested with S. aureus and E. coli. A synergetic effect was observed, being the best antibacterial results obtained for AgMNs@oflox for the strain S. aureus ATCC 25923, with MIC and MIB values of $5 \mu \mathrm{g} / \mathrm{mL}$ and $25 \mu \mathrm{g} / \mathrm{mL}$ [18].

Other metal ions, especially the mesoporous silica copper and nickel-supported nanoparticles, MNs-Schiff base (SB)-Cu and MNs-SB-Ni, presented a bactericidal and bacteriostatic effect against S. aureus and E. coli [19]. However, gold nanoparticles' inexistent toxicity towards living organisms (prokaryotic and eukaryotic), as well as their known photothermal behaviour, make gold-based systems viable and biocompatible building blocks for complex nanostructures of biological application, namely their possible conjugation with antibacterial agents for the application in living eukaryotic systems.

Thus, in this work we present the synthesis of core-shell gold-silica based mesoporous silica nanoparticles for the effective delivery of ofloxacin and amoxicillin towards Staphylococcus aureus, methicillin-resistant Staphylococcus aureus (MRSA), Escherichia coli and Pseudomonas aeruginosa. Synergetic effects and drug delivery efficiency between the antibiotics and nanoparticles will also be studied, aiming for a significant decrease of administered antibiotic, while maintaining bactericidal performance.

\section{Materials and methods}

Hydrogen tetrachloroaurate(III) hydrate ( $\left.\mathrm{HAuCl}_{4}, 99 \%\right)$, sodium citrate tribasic, ethylene glycol (EG) hexadecyltrimethylammonium bromide (CTAB, $\geq 98 \%$ ), ammonium nitrate, amoxicillin, ofloxacin, ethanol (EtOH) and methanol $(\mathrm{MeOH})$ were used as purchased from Sigma-Aldrich. Tetraethyl orthosilicate (TEOS, 99.999\%), sodium hydroxide $(\mathrm{NaOH})$ and sodium chloride $(\mathrm{NaCl}, 99 \%)$ were bought from Alfa Aesar and PanReact, respectively. Dimethyl sulfoxide (DMSO) was acquired from CarloErba. All reagents were used as bought and all solutions unless otherwise indicated, were prepared in deionised (DI) MiliQ water. Antibacterial assays were performed against gram-negative Escherichia coli ATCC $8739^{\mathrm{mm}}$ (E. coli) and Pseudomonas aeruginosa $\mathrm{ATCC}^{\circ} 9027^{\mathrm{TM}}$ (P. aeruginosa), and gram-positive bacteria Staphylococcus aureus ATCC $^{\circ} 6538^{\mathrm{TM}}$ (S. aureus), methicillin-resistant Staphylococcus aureus ATCC $33591^{\mathrm{Tm}}$ (MRSA). Muller Hinton Agar (MHA), Muller Hinton Broth (MHB) and Trypto Casein-Soy Agar (TSA) were obtained from Biokar Diagnostics (Allonne, France).

\subsection{Instrumentation}

Gold concentration was obtained, at $267 \mathrm{~nm}$, by Inductively Coupled Plasma-Atomic Emission Spectrometer (ICP-AES, Horiba Jobin-Yvon), equipped with a $40.68 \mathrm{MHz}$ RF generator, Czerny-Turner monochromator with $1.00 \mathrm{~m}$ (sequential), autosampler AS500 and CMA (Concomitant Metals Analyzer), from REQUIMTE Laboratory of Analysis from FCT-UNL (Portugal). UV-Vis absorption spectra were acquired on a Jasco V-650 spectrophotometer (Jasco Corporation, Tokyo, Japan) and Nanodrop 1000 Spectrophotometer (ThermoFisher); nanoparticle size distributions and zeta potential were measured using a dynamic light scattering Malvern Nano Zetasizer, with a $633 \mathrm{~nm}$ laser diode, from Proteomass-Bioscope facility (Caparica, Portugal). Pore size distribution and surface areas were determined by $\mathrm{N}_{2}$ adsorption/desorption at $77 \mathrm{~K}$, in a Micromeritics ASAP 2010 (Micrometrics Instrument 
Corporation, Norcross, USA) (Accelerated Surface Area and Porosimetry), at the Laboratory of Analysis from FCT-UNL. Specific surface areas $\left(\mathrm{S}_{\mathrm{BET}}\right)$ pore volume were estimated using Brunauer Emmett and Teller (BET) and Barrett-Joyner-Halenda (BJH) methods. Infrared spectra (IR) were collected on a PerkinElmer Spectrum Two spectrometer, FTIR-ATR (Perkin Elmer Inc., Llantrisant, UK) and $X$-ray Diffraction (XRD) spectra on a RIGAKU MiniFlex II $\mathrm{X}$-ray diffractometer, equipped with a $\mathrm{Cu}$-Ka source at $30 \mathrm{kV} / 15 \mathrm{~mA}$, between $2^{\circ}$ and $80^{\circ}$, at the Laboratory of Analysis from FCT-UNL.

Bacterial suspensions' turbidity was adjusted with the aid of a DEN-1B McFarland Densiometer (Grant-bio) and quantified in a UV-Vis CLARIOstar spectrophotometer (BMG Labtech). During antibacterial assays, asepsis was ensured using a laminar flux chamber Steril-VBH. Incubations were performed within a Mermmet Incubator B50. Diffusion assays were performed in sterile paper disks with a diameter of $6 \mathrm{~mm}$, bought at Bacto disks, and microdilution assays in sterile 96-well plates, bought at Greiner Bio-One.

SEM images were obtained in a Quanta 650 FEG operating between 5 and $30 \mathrm{kV}$ and $3.6 \times 10^{-4} \mathrm{~Pa}$ of vacuum in the chamber. Transmission electron microscopy (TEM) images were obtained in a JEOL JEM-2100-HT operating at $200 \mathrm{kV}$, TEM images were collected using a "OneView" $4 \mathrm{k} \times 4 \mathrm{k} C \mathrm{CD}$ camera.

\subsection{Synthesis of gold-silica mesoporous nanoparticles (Au@MNs)}

Gold nanoparticles (AuNPs) were synthesised following the traditional Turkevich method for the production of $20 \mathrm{~nm}$ AuNPs [20, 21]. $4.9 \mathrm{mg}$ of $\mathrm{HAuCl}_{4}$ were dissolved in DI MiliQ water and placed under reflux for approx. $30 \mathrm{~min}$. Separately, $1.25 \mathrm{~mL}$ of a $10 \mathrm{mg} / \mathrm{mL}$ sodium citrate tribasic aqueous solution was prepared and poured onto the reaction pot and left to stir for an additional $15 \mathrm{~min}$ under reflux. Heating was kept until a deep wine-red colour was obtained. Citrate-capped AuNPs were cooled at room temperature and stored at $4{ }^{\circ} \mathrm{C}$. For the growth of a mesoporous silica shell [18, 22], $6.25 \mathrm{~mL}$ of AuNP colloid $\left(9.2 \times 10^{11}\right.$ particles $\left./ \mathrm{mL}\right)$ were mixed with $10 \mathrm{~mL}$ of a $15 \mathrm{mg} / \mathrm{mL}$ CTAB aqueous solution and stirred for $30 \mathrm{~min}$ at $50^{\circ} \mathrm{C}$. In this order, $30 \mathrm{~mL}$ of DI MiliQ water, $10 \mathrm{~mL}$ of EG and $0.7 \mathrm{~mL}$ of a $1 \mathrm{M} \mathrm{NaOH}$ aqueous solution were poured into the reaction pot and vigorously stirred for $30 \mathrm{~min}$ at $80^{\circ} \mathrm{C}$. Then, $750 \mu \mathrm{L}$ of TEOS were dropwisely added to the reaction mixture and stirred for $2 \mathrm{~h}$ at $80^{\circ} \mathrm{C}$. The resulting Au@MNs material was centrifuged (8.000 rpm, $10 \mathrm{~min})$, washed three times with $\mathrm{MeOH}$ and dried at open-air conditions.
Blank mesoporous silica nanoparticles (MNs) were obtained following the same protocol, without the addition of citrate-capped AuNPs. For template removal, the Au@MNs and $\mathrm{MNs}$ were resuspended in $20 \mathrm{~mL}$ of a $30 \mathrm{mg} / \mathrm{mL}$ ammonium nitrate methanolic solution and stirred for $1 \mathrm{~h}$ at $60^{\circ} \mathrm{C}$, followed by centrifugation and washing in $\mathrm{MeOH}$. This process was repeated twice and confirmed by IR spectroscopy for both materials.

\subsection{Loading and release trials}

Amoxicillin and ofloxacin were loaded, separately, into the pores of MNs and Au@MNs. Briefly, for ofloxacin, $50 \mathrm{mg}$ of each material were resuspended in $1 \mathrm{~mL}$ of DMSO and mixed with $1 \mathrm{~mL}$ of a suspension of the antibiotic $(10 \mathrm{mg} /$ $\mathrm{mL}$ ), in DMSO. Amoxiciillin loading followed the same procedure but in water. Reaction mixtures were let to stir for $24 \mathrm{~h}$ at $20^{\circ} \mathrm{C}$. After $24 \mathrm{~h}, 3 \mathrm{~mL}$ of EtOH were added to the reaction pots to stop the loading process and the product centrifuged (8.000 rpm, 5 min). The loaded NPs (Amox@ MNs, Oflox@MNs,Amox@Au@MNs and Oflox@Au@MNs) were washed several times with EtOH. Loading yields (L\%) and loading capacities (LC) were determined by UV-vis spectroscopic quantification and mass balances (Eqs. 1 and 2), in triplicates, at $271 \mathrm{~nm}\left(\varepsilon=871.9 \mathrm{M}^{-1} \mathrm{~cm}^{-1}\right)$ and $292 \mathrm{~nm}\left(\varepsilon=36543.6 \mathrm{M}^{-1} \mathrm{~cm}^{-1}\right)$ for amoxicillin and ofloxacin, respectively.

$L \%=\frac{m a_{i}-m a_{e}}{m a_{i}} \times 100$

$L C(m g / g)=\frac{m a_{i}-m a_{e}}{m_{N P s}}$

where $m a_{i}(\mathrm{mg})$ is the initial amount of the antibiotic, $m a_{e}$ (mg) the amount of antibiotic in the supernatant, and $m_{N P S}$ (mg) the mass of MNs or Au@MNs.

Release profiles were performed for all materials and measured in a Nanodrop 1000 Spectrophotometer. Briefly, $4 \mathrm{mg}$ of each material were resuspended in $2 \mathrm{~mL}$ of DMSO and stirred at $37^{\circ} \mathrm{C} .0 .5 \mathrm{~mL}$ aliquots of each reaction pot were collected after $30 \mathrm{~min}, 1 \mathrm{~h}, 2 \mathrm{~h}, 4 \mathrm{~h}, 6 \mathrm{~h}, 12 \mathrm{~h}, 24 \mathrm{~h}$, $48 \mathrm{~h}, 72 \mathrm{~h}$ and $96 \mathrm{~h}$ (4 days), centrifuged and quantified by UV-vis spectroscopy. Amoxicillin was quantified at $276 \mathrm{~nm}\left(\varepsilon=141.7 \mathrm{M}^{-1} \mathrm{~cm}^{-1}\right)$ and ofloxacin at $292 \mathrm{~nm}$ $\left(\varepsilon=2825.8 \mathrm{M}^{-1} \mathrm{~cm}^{-1}\right)$. The same volume was, then, poured back into the reaction pot. The total amount of released antibiotics was determined by mass balance and their transport profiles estimated by the semi-empirical Korsmeyer-Peppas model (Eq. 3).

$\frac{\mathrm{M}_{\mathrm{t}}}{\mathrm{M}_{\infty}}=\mathrm{k} \times t^{n}$ 
where $M_{t}$ is the absolute cumulative amount of released antibiotic at time $t, M_{\infty}$ is the total amount of antibiotic in MNs or Au@MNs at equilibrium, $k$ is the diffusion coefficient that incorporates structural and geometric characteristics of each material, and $n$ is the release parameter that determines the specific transport mechanism [23].

\subsection{Antibacterial activity assays}

The antibacterial activity of the synthesised nanoparticles was assayed against both Gram-negative bacteria-Escherichia coli $\left(\right.$ ATCC $\left.^{\circledR} 8739^{\mathrm{Tm}}\right)$ and Pseudomonas aeruginosa (ATCC ${ }^{\circledR} 9027^{\mathrm{TM}}$ ) —and Gram-positive bacteria-Staphylococcus aureus (ATCC ${ }^{\oplus} 6538^{\mathrm{TM}}$ ), methicillinresistant Staphylococcus aureus (ATCC ${ }^{\circledR} 33591^{\text {TM}}$ ) (MRSA) (see Table 1). Bacteria were kept frozen at $-70^{\circ} \mathrm{C}$ in broth containing glycerol $(15 \% \mathrm{v} / \mathrm{v})$.

All nanoparticle powders and antibiotics were suspended in DMSO to concentrations of $8 \mathrm{mg} / \mathrm{mL}$ and $1 \mathrm{mg} /$ $\mathrm{mL}$, respectively (Table 2 ).

Initially, antibacterial activity was assayed by the agar diffusion method proposed by Kirby-Bauer [32]. Frozen microorganisms were initially inoculated in TSA and incubated overnight at $35 \pm 2{ }^{\circ} \mathrm{C}$. Isolated colonies were transferred to saline medium $(\mathrm{NaCl}, 0.85 \% \mathrm{~m} / \mathrm{v})$ and the turbidity of the suspension was adjusted to 0.5 on the McFarland scale (approx. $1.5 \times 10^{8} \mathrm{CFU} / \mathrm{mL}$ ) [19]. Then, with a sterile swab, bacteria suspensions were spread on the surface of MHA Petri dishes, onto which sterile paper disks were set. Each disk was carefully loaded with $10 \mu \mathrm{L}$ of each sample suspension and the plates were incubated, in the dark, for $24 \mathrm{~h}$ at $35 \pm 2{ }^{\circ} \mathrm{C}$. Antibacterial activity was evaluated, in duplicates, by measuring the diameter of the growth inhibition zone around the sterile paper disks, compared with those of controls. Solvent-loaded sterile paper disks were used as negative control.

To evaluate and quantify the bactericidal and bacteriostatic effects of the tested nanocomposites, all samples were assayed by the broth microdilution method in 96-well microplate. Briefly, two-fold serial dilutions of each sample and controls were prepared in sterile MHB to a final volume of $100 \mu \mathrm{L}$ per well. Then, each well was inoculated with the previously prepared bacteria suspensions. The microplates were incubated, in the dark, at $35 \pm 2{ }^{\circ} \mathrm{C}$ for $24 \mathrm{~h}$. Free antibiotics, MNs and Au@MNs incubated in the presence of bacteria were used as positive controls, while bacteria incubated in the absence of NPs were used as negative controls. NPs and antibiotics incubated in the absence of bacteria were used as sterile controls. Each sample was tested in duplicate.

Upon the appointed time, an aliquot of each well was spread onto TSA Petri dishes and incubated in the dark, for an additional $24 \mathrm{~h}$ at $35 \pm 2{ }^{\circ} \mathrm{C}$. All 96 -well plates were then analysed, with each well's turbidity being observed at both naked-eye and in a 96-well plate ClarioStar spectrophotometer, at $600 \mathrm{~nm}$. The obtained results were compared with those obtained after the $24 \mathrm{~h}$-incubated TSA Petri dishes. A minimum inhibitory concentration (MIC) was considered for a reduction in turbidity/viability of approx. $50 \%$, and a minimum bactericidal concentration

Table 1 Bacterial strains specifications

\begin{tabular}{|c|c|c|}
\hline Strain & Relevant phenotype & Ref. \\
\hline E. coli ATCC 8739 & Gram-negative; ofloxacin sensitive & {$[24,25]$} \\
\hline P. aeruginosa ATCC 9027 & Gram-negative; amoxicillin resistant, ofloxacin sensitive & {$[26,27]$} \\
\hline S. aureus ATCC 6538 & Gram-positive, methicillin sensitive, ofloxacin sensitive & {$[28,29]$} \\
\hline S. aureus ATCC 33591 (MRSA) & Gram-positive, methicillin/amoxicillin resistant, ofloxacin sensitive & {$[30,31]$} \\
\hline
\end{tabular}

ATCC American Type Culture Collection

Table 2 Summary of all tested nanoparticles, free antibiotics and controls, with their stock concentrations

\begin{tabular}{lllllll}
\hline Particles & $\mathrm{ID}$ & $\mathrm{m}(\mathrm{mg})$ & $\mathrm{V}_{\text {DMsO }}(\mathrm{mL})$ & ]$_{\text {stock }}(\mathrm{mg} / \mathrm{mL})$ & $\mathrm{m}_{\text {Drug }}(\mathrm{ug})$ & {[]$_{\text {Drug }}(\mathrm{mg} / \mathrm{mL})$} \\
\hline MNs & 1 & 4.00 & 0.5 & 8.00 & - & - \\
Au@MNs & 2 & 4.00 & 0.5 & 8.00 & - & - \\
Oflox@MNs & 3 & 4.00 & 0.5 & 8.00 & 221.9 & 0.4 \\
Amox@MNs & 4 & 4.00 & 0.5 & 8.00 & 491.0 & 1.0 \\
Oflox@Au@MNs & 5 & 4.00 & 0.5 & 8.00 & 165.7 & 0.3 \\
Amox@Au@MNs & 6 & 4.00 & 0.5 & 8.00 & 563.4 & 1.1 \\
Amox free & 7 & 1.00 & 1.0 & 1.00 & - & - \\
Oflox free & 8 & 1.00 & 1.0 & 1.00 & - & - \\
DMSO & 9 & - & 1.0 & - & - & - \\
\hline
\end{tabular}


(MBC) for a reduction in $99 \%$, when compared to that of the controls [33].

\section{Results and discussion}

\subsection{Synthesis of Gold@mesoporous silica nanoparticles and characterisation}

Gold nanoparticles (AuNP) were obtained by the Turkevich method, leading to the synthesis of citrate-capped AuNPs, that were initially characterised by UV-Vis absorption spectroscopy and Dynamic Light Scattering (DLS) techniques for the determination of shape, size and zeta potential. The as-synthesised deep-red coloured AuNPs ( 50 $\mu \mathrm{L}$ ) were diluted in $2.95 \mathrm{~mL}$ of MiliQ water $(\mathrm{pH}=7.0)$, giving place to a light-red dispersion with a typical plasmonic band in its absorption spectra at ca. $525 \mathrm{~nm}$, characteristic of sphere-like dispersed AuNPs (Figure S1) [21, 34]. Their average hydrodynamic diameter (HD), polydispersion index (PDI) and zeta potential ( $\zeta$ ) were of $27 \pm 5 \mathrm{~nm}$, $0.28 \pm 0.06$ and $-30 \pm 4 \mathrm{mV}$ (for $n$ replicates, with $n=8$ ), confirming not only their high stability but also the effective capping of AuNPs surface with citrate molecules. Obtained HDs are also according to those stated in literature for the same synthetic methodology [21, 35]. The final gold concentration in AuNPs purified dispersions was obtained by ICP, with $[\mathrm{Au}]=8.24 \times 10^{-4} \mathrm{M}$ corresponding to an average AuNPs concentration of $9.2 \times 10^{11}$ particles $/ \mathrm{mL}$.

Gold mesoporous nanoparticles (Au@MNs) were obtained through the growth of a silica shell by a wellestablished and reported Stöber method for the synthesis of MCM-41 [18, 36, 37]. Here, TEOS was used as silica source, CTAB as a cationic templating surfactant, ethylene glycol as stabiliser and $\mathrm{NaOH}$ as reducing and morphological agent. MCM-41 mesoporous silica nanoparticles (MNs) produced in the absence of gold cores were used as control for all experiments. Both nanosystems were obtained in the form of dry powders and were Fig. 1 Top |Characterization of Au@MNs nanoparticles: (A)TEM image of Au@ MNs-inset: close up on single Au@MNs (scale $69 \mathrm{~nm}$ ). Size distribution histograms (for a population of $\mathrm{N}=50$ ) of (B) Au@MNs and (C) Au-cores. Characteristic type-IV N $\mathrm{N}_{2}$ isotherms of mesoporous (D) MNs and (E) Au@MNs. Bottom | Summary of MNs and Au@MNs physical properties, obtained from the analysis of TEM images and BET and BJH models application in physisorption assays characterised by DLS, FTIR, XRD TEM, SEM, ICP and $\mathrm{N}_{2}$ adsorption-desorption isotherms (Figs. 1, 2).

MNs nanoparticles had their HD and water stability determined by DLS assays (HD $=443 \pm 19 \mathrm{~nm}$, $\mathrm{PDI}=0.45 \pm 0.09$ and $\zeta=-21 \pm 0.2 \mathrm{mV}$ ), showing similar results to those already reported for the same system, in the same conditions [37]. The successful production of silica nanoparticles was validated by their FTIR and XRD spectra. The presence of characteristic Si-O-Si $\left(1225 \mathrm{~cm}^{-1}\right.$, $\left.1065 \mathrm{~cm}^{-1}, 445 \mathrm{~cm}^{-1}\right)$, Si-O $\left(965 \mathrm{~cm}^{-1}, 795 \mathrm{~cm}^{-1}\right)$ and $\mathrm{Si}-\mathrm{OH}\left(3388 \mathrm{~cm}^{-1}, 1645 \mathrm{~cm}^{-1}\right)$ vibrations in the obtained FTIR spectra confirm the presence of a silica matrix with surface $\mathrm{H}$-bonded silanols (Figure S2). Its corresponding XRD pattern revealed a broad wave packet at ca. $20^{\circ}-30^{\circ}$, arising from the formation of a predominant amorphous silica phase in MNs nanoparticles, and well-defined diffraction peaks at $2.30^{\circ}, 3.86^{\circ}, 4.42^{\circ}$ and $5.86^{\circ}$, corresponding to (100), (110), (200), (210) diffraction planes, respectively (Figure S3). The presence of these planes is typically associated with highly-ordered hexagonal mesoporous MCM-41 structures [38-40].

A high mesoporosity was confirmed by $\mathrm{N}_{2}$ adsorption-desorption type IV isotherms, with an accentuated adsorption step behaviour at $\mathrm{p} / \mathrm{p}_{0}$ ca. $0.30-0.35$ (Fig. 3e). Surface area, porous volume and pore diameter were assessed through Brunauer Emmett and Teller (BET) and Barrett-Joyner-Halenda (BJH) methods, with values of $940.22 \mathrm{~m}^{2} / \mathrm{g}, 0.884 \mathrm{~cm}^{3} / \mathrm{g}$ and $34.5 \AA$, respectively.

Au@MNs nanoparticles were successfully obtained and showed excellent water dispersibility and stability, with HDs of about $333 \pm 4 \mathrm{~nm}$, for PDI $=0.16 \pm 0.01$ and $\zeta=-39 \pm 1 \mathrm{mV}$. Total template removal was confirmed by FTIR spectra of the nanocomposite through the loss of the typical strong C-H stretching between 2900 and $3000 \mathrm{~cm}^{-1}$ (Figure S2). However, it should be noted that citrate distinct peaks at ca. $2970 \mathrm{~cm}^{-1}, 1730 \mathrm{~cm}^{-1}$, $1390 \mathrm{~cm}^{-1}, 1230 \mathrm{~cm}^{-1}$ and $880 \mathrm{~cm}^{-1}$ are yet visible, hinting the existence of sodium citrate anhydrous-like species and consequently an effective encapsulation of citratecapped AuNPs. Silica shell growth was also confirmed through FTIR spectroscopy, with characteristic Si-O-Si $\left(1068 \mathrm{~cm}^{-1}, 445 \mathrm{~cm}^{-1}\right)$, Si-O $\left(965 \mathrm{~cm}^{-1}, 799 \mathrm{~cm}^{-1}\right)$ and $\mathrm{Si}-\mathrm{OH}\left(3337 \mathrm{~cm}^{-1}, 1641 \mathrm{~cm}^{-1}\right)$ stretchings and bendings displayed in Au@MNs FTIR spectra. Similar to MNs, and again confirming the presence of an ordered mesoporous and amorphous silica shell, Au@MNs'XRD pattern showed a broad signal at $\mathrm{ca} \cdot 20^{\circ}-30^{\circ}$ along with well-defined peaks $2.20^{\circ}$ and $3.80^{\circ}$, corresponding to $\mathrm{Si}(100)$ and $\mathrm{Si}(110)$ planes, respectively. Interestingly, weak but defined peaks at $38.18^{\circ}, 44.28^{\circ}, 64.64^{\circ}$ and $77.94^{\circ}$ match those previously reported in literature for Au-silica nanocomposites [41, 42], corresponding to $\mathrm{Au}(111), \mathrm{Au}(200), \mathrm{Au}(220)$ and $\mathrm{Au}(311)$ planes, respectively (Fig. 2).

TEM images confirmed what above-mentioned techniques already hinted for, showing highly porous welldefined spherical nanoparticles centred by a single AuNP core, with average diameters of $213 \pm 5 \mathrm{~nm}$ and $26 \pm 3 \mathrm{~nm}$, respectively (Fig. $1 \mathrm{a}-\mathrm{C}$ and Figure $\mathrm{S} 4$ ). $\mathrm{N}_{2}$ adsorption-desorption assays developed type IV isotherms, typical of 

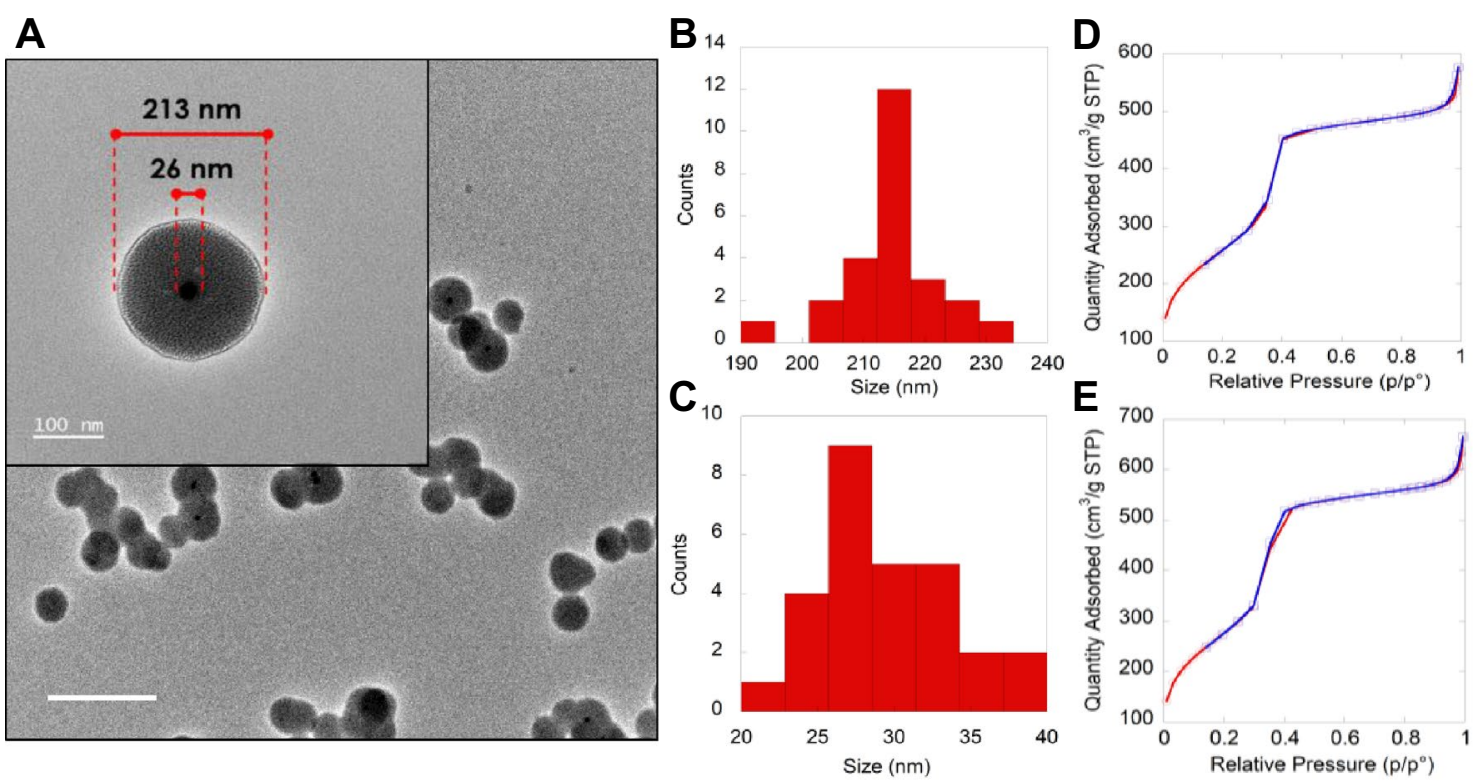

\begin{tabular}{|c|c|}
\hline MNs & \\
\hline \multicolumn{2}{|l|}{ SURFACEAREA } \\
\hline BET Surface area & $940.22 \mathrm{~m}^{2} / \mathrm{g}$ \\
\hline $\begin{array}{l}\text { BJH Adsorption cumulative surface area of pores } \\
\text { between } 17 \AA \text { and } 3000 \AA \text { diameter }\end{array}$ & $1028.4 \mathrm{~m}^{2} / \mathrm{g}$ \\
\hline $\begin{array}{l}\text { BJH Desorption cumulative surface area of pores } \\
\text { between } 17 \AA \text { and } 3000 \AA \text { diameter }\end{array}$ & $1021.1 \mathrm{~m}^{2} / \mathrm{g}$ \\
\hline \multicolumn{2}{|l|}{ PORE VOLUME } \\
\hline $\begin{array}{l}\text { BJH Adsorption cumulative volume of pores } \\
\text { between } 17 \AA \text { and } 3000 \AA \text { diameter }\end{array}$ & $0.884 \mathrm{~cm}^{3} / \mathrm{g}$ \\
\hline $\begin{array}{l}\text { BJH Desorption cumulative volume of pores } \\
\text { between } 17 \AA \text { and } 3000 \AA \text { diameter }\end{array}$ & $0.881 \mathrm{~cm}^{3} / \mathrm{g}$ \\
\hline \multicolumn{2}{|l|}{ PORE SIZE } \\
\hline BJH Adsorption average pore diameter & $34.4 \AA$ \\
\hline BJH Desorption average pore diameter & $34.5 \AA$ \\
\hline
\end{tabular}

Fig. 1 Top-characterization of Au@MNs nanoparticles: a TEM image of Au@MNs-inset: close up on single Au@MNs (scale $69 \mathrm{~nm}$ ). Size distribution histograms (for a population of $\mathrm{N}=50$ ) of b Au@MNs and c Au-cores. Characteristic type-IV $\mathrm{N}_{2}$ isotherms

mesoporous materials, with surface area, porous volume and pore size of $1028.13 \mathrm{~m}^{2} / \mathrm{g}, 1.111 \mathrm{~cm}^{3} / \mathrm{g}$ and $33.8 \AA$, respectively (Fig. $1 \mathrm{~d}$ ). Note that, the increase in surface area and porous volume is consequence of Au@MNs larger particle diameter. Au content in Au@MNs was determined by ICP, amounting to $6.83 \mathrm{mg}$ of Au per gram of nanoparticles. SEM micrographs of MNs and Au@MNs showed a particle size of $193 \pm 27 \mathrm{~nm}$ and $194 \pm 23 \mathrm{~nm}$, respectively.

\subsection{Antibiotics loading and release studies}

The physical adsorption of amoxicillin and ofloxacin into nanoparticles (i.e. MNs and Au@MNs) pores was
Au@MNs

\begin{tabular}{|c|c|}
\hline \multicolumn{2}{|l|}{ PARTICLE SIZE (TEM) } \\
\hline Particle diameter $[\mathrm{AVG} \pm \mathrm{STDV}]$ & $212 \pm 9 \mathrm{~nm}$ \\
\hline \multicolumn{2}{|l|}{ SURFACEAREA } \\
\hline BET Surface area & $1028.13 \mathrm{~m}^{2} / \mathrm{g}$ \\
\hline $\begin{array}{l}\text { BJH Adsorption cumulative surface area of pores } \\
\text { between } 17 \AA \text { and } 3000 \AA \text { diameter } \\
\text { BJH Desorption cumulative surface area of pores } \\
\text { between } 17 \AA \text { and } 3000 \AA \text { diameter }\end{array}$ & $\begin{array}{r}1288.5 \mathrm{~m}^{2} / \mathrm{g} \\
1313.9 \mathrm{~m}^{2} / \mathrm{g}\end{array}$ \\
\hline \multicolumn{2}{|l|}{ PORE VOLUME } \\
\hline $\begin{array}{l}\text { BJH Adsorption cumulative volume of pores } \\
\text { between } 17 \AA \text { and } 3000 \AA \text { diameter } \\
\text { BJH Desorption cumulative volume of pores } \\
\text { between } 17 \AA \text { and } 3000 \AA \text { diameter }\end{array}$ & $\begin{array}{l}1.087 \mathrm{~cm}^{3} / \mathrm{g} \\
1.111 \mathrm{~cm}^{3} / \mathrm{g}\end{array}$ \\
\hline \multicolumn{2}{|l|}{ PORE SIZE } \\
\hline BJH Adsorption average pore diameter & $33.7 \AA$ \\
\hline BJH Desorption average pore diameter & $33.8 \AA$ \\
\hline
\end{tabular}

of mesoporous $\mathbf{d}$ MNs and e Au@MNs. Bottom—summary of MNs and Au@MNs physical properties, obtained from the analysis of TEM images and BET and BJH models application in physisorption assays

achieved in MiliQ water ( $\mathrm{pH}$ 7), or DMSO, respectively. The loading solvents were selected to ensure good solubility and homogeneity of each antibiotic, and nanoparticles, during the loading process. Both antibiotic loadings were evaluated after $24 \mathrm{~h}$ incubations, at $20^{\circ} \mathrm{C}$, and upon each wash's supernatant quantification by UV-vis absorbance spectroscopy. Amoxicillin and ofloxacin solutions of $1 \times 10^{-5} \mathrm{M}$, prepared in MiliQ water and DMSO respectively, were used as standards. Their spectra were collected at $20^{\circ} \mathrm{C}$, with absorption maxima centred at $271 \mathrm{~nm}$, for amoxicillin, and $292 \mathrm{~nm}$, for ofloxacin. The latter also presenting a shoulder at $330 \mathrm{~nm}$ (Fig. 3a). Maxima were used to quantify supernatants, with 


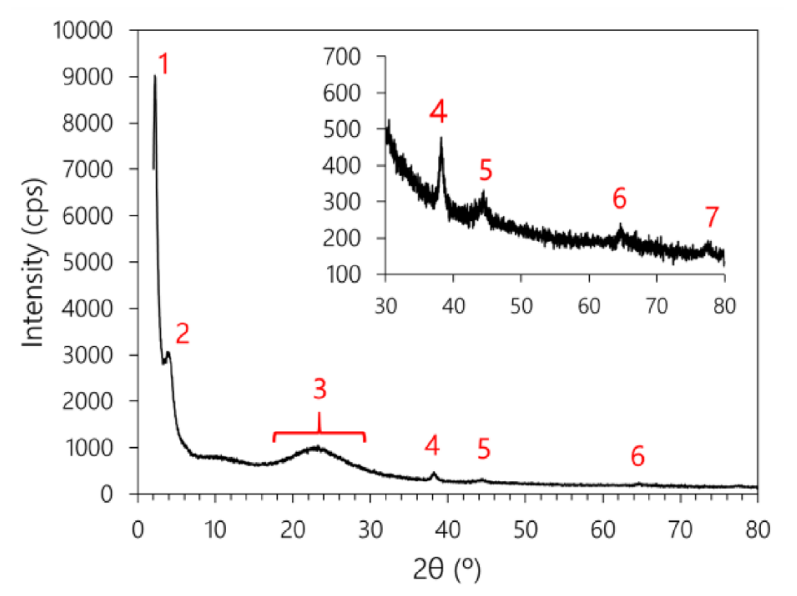

\begin{tabular}{lrrrrl} 
PEAK & $2 \theta\left({ }^{\circ}\right)$ & I (cps) & PLANE $d_{\text {hkl }}(\AA)$ & MATERIAL \\
\hline 1 & 2.20 & 9008 & $(100)$ & 40.12 & \\
2 & 3.8 & 3072 & $(110)$ & 22.52 & SiO $_{2}$ \\
3 & $20-(23)-30$ & 927 & $(200)$ & - & \\
\hline 4 & 38.18 & 477 & $(111)$ & - & \\
5 & 44.28 & 322 & $(200)$ & - & \\
6 & 64.64 & 240 & $(220)$ & - & $\mathrm{Au}$ \\
7 & 77.94 & 191 & $(311)$ & - & \\
\hline
\end{tabular}

Fig. 2 Left-Au@MNs XRD pattern for $2 \theta$ angles between $2^{\circ}$ and $80^{\circ}$-inset: close up on Au typical peaks for angles between $30^{\circ}$ and $80^{\circ}$. Right-summary on the registered peaks and associated intensities, $2 \theta$ angles, atomic planes, interplanar $d$-spacing $\left(d_{h k l}\right)$ and type of material

amoxicillin encapsulation reaching $L \%$ values of $62 \%$ (i.e. $L C=122.75 \mathrm{mg} / \mathrm{g}$ ) and $70 \%$ (i.e. $\mathrm{LC}=140.85 \mathrm{mg} / \mathrm{g}$ ), for MNs and Au@MNs respectively. Conversely, ofloxacin loadings reached $L \%$ values of $31 \%$ (i.e. $L C=62.32 \mathrm{mg} / \mathrm{g}$ ) and $35 \%$ (i.e. $L C=42.18 \mathrm{mg} / \mathrm{g}$ ), for MNs and Au@MNs respectively (Fig. 3b).

The systems displayed great loading capacity matching already published silica-based materials for the same antibiotics, some of which had to undergo a previous organofunctionalisation process of their pores and surfaces to attain their loading levels (Table 3).Amox@Au@ MNs showed $L \%$ and $L C$ values competitive with those obtained for surface-modified mesoporous silicas; while their Au-free counterpart (Amox@MNs) bested, by far, any as-synthesised mesoporous silica material reported in literature. Here in produced ofloxacin-loaded materials, exhibited great encapsulation appetency, reproducing similar results to those of Nuti et al. [18]. The scarceness of reported ofloxacin-loaded mesoporous silica nanomaterials, represents an opportunity for the introduction of such materials in bacteria eradication while aiming for a reduction in prescribed ofloxacin quantities.

Amoxicillin and ofloxacin loaded materials were also characterised by DLS measurement of their size and zeta potential.Amox@Au@MNs and Oflox@Au@MNs showing larger HDs (454 $\pm 24 \mathrm{~nm}$ and $557 \pm 10 \mathrm{~nm}$, respectively) and lower $\zeta(-17 \pm 1 \mathrm{mV}$ and $-19 \pm 1 \mathrm{mV}$, respectively) can be attributed to an efficient functionalisation of pores and surfaces, although with a destabilising effect.

Release assays were performed in DMSO at $37^{\circ} \mathrm{C}$, as all samples were dispersed in DMSO for $1 \mathrm{~h}$, prior to its application in antimicrobial activity assays. The release assay was followed by absorbance measurements of all supernatants, at each drug maximum, for 5 days. Amoxicillin release maxima for $\mathrm{MNs}$ and $\mathrm{Au} @ \mathrm{MNs}$ were of $\mathrm{ca} .15 \%$ and $10 \%$ (i.e. $19 \mathrm{mg} / \mathrm{g}$ and $15 \mathrm{mg} / \mathrm{g}$ ), respectively (Fig. 3c), while ofloxacin released maxima were of ca. $14 \%$ and $12 \%$ (i.e. $9 \mathrm{mg} / \mathrm{g}$ and $7 \mathrm{mg} / \mathrm{g}$ ) (Fig. $3 \mathrm{~d}$ ). Such results indicate a delaying effect of Au-cores presence over antibiotics release, which was confirmed by fitting the collected data to the semi-empirical Korsmeyer-Peppas. Through a linearization of Eq. 3 we have,

$\log \frac{M_{t}}{M_{\infty}}=\log k+n \cdot \log t$

And fitting to the already treated and logaritmised data, it was possible to determine both $n$ and $k\left(\mathrm{~h}^{-n}\right)$ for all antibiotic-nanoparticles systems, summarised in Table 4 (see figure S5). With all systems presenting a spherical shape and having values of $n<0.43$, it can be concluded that, as expected, we are working with non-swellable matrixes where diffusion phenomena rule antibiotics mass transfer, from nanoparticles to the surrounding medium. In these cases, diffusion follows a quasi-fickian model with diffusion rates as functions of time, for $k$ values defined by $t^{-n}$ [49-51].

\subsection{Antibacterial activity assays}

The antibacterial activity of each system was initially tested in sterile paper disks, which were placed in contact with E. coli, P. aeruginosa, S. aureus and MRSA cultures. All nanoparticles were loaded at a concentration of $8.0 \mathrm{mg}_{\mathrm{NP}} /$ $\mathrm{mL}$, corresponding to: $1.0 \mathrm{mg}_{\mathrm{Amox}} / \mathrm{mL}$ and $1.1 \mathrm{mg}_{\mathrm{Amox}} / \mathrm{mL}$ for Amox@MNs and Amox@Au@MNs, respectively; and 0.4 $\mathrm{mg}_{\text {oflox }} / \mathrm{mL}$ and $0.3 \mathrm{mg}_{\text {oflox }} / \mathrm{mL}$ for Oflox@MNs and Oflox@ Au@MNs. The formation of growth inhibition zones and their diameters are evidence of each formulation's antibacterial activity, when compared to those formed, or not, in the presence of free amoxicillin, free ofloxacin and their blank MNs and Au@MNS counterparts. 

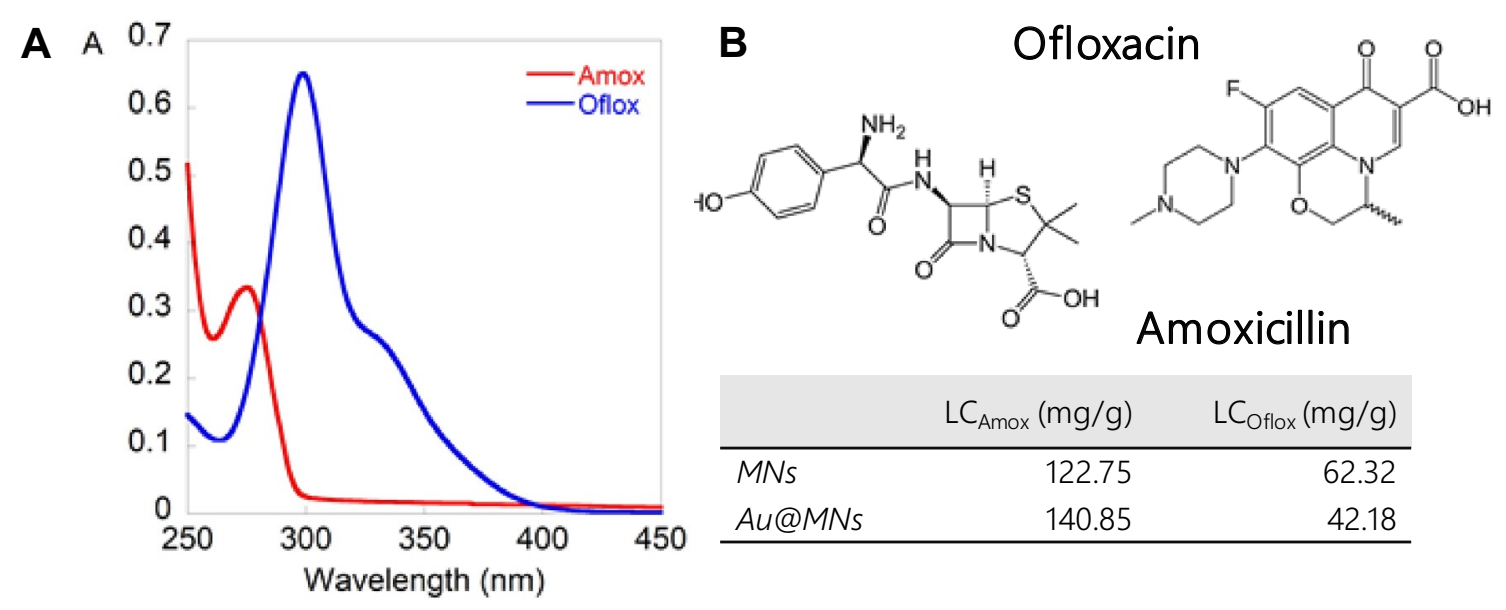

\begin{tabular}{lrr} 
& $\mathrm{LC}_{\text {Amox }}(\mathrm{mg} / \mathrm{g})$ & $\mathrm{LC}_{\text {Oflox }}(\mathrm{mg} / \mathrm{g})$ \\
\hline MNs & 122.75 & 62.32 \\
Au@MNs & 140.85 & 42.18 \\
\hline
\end{tabular}
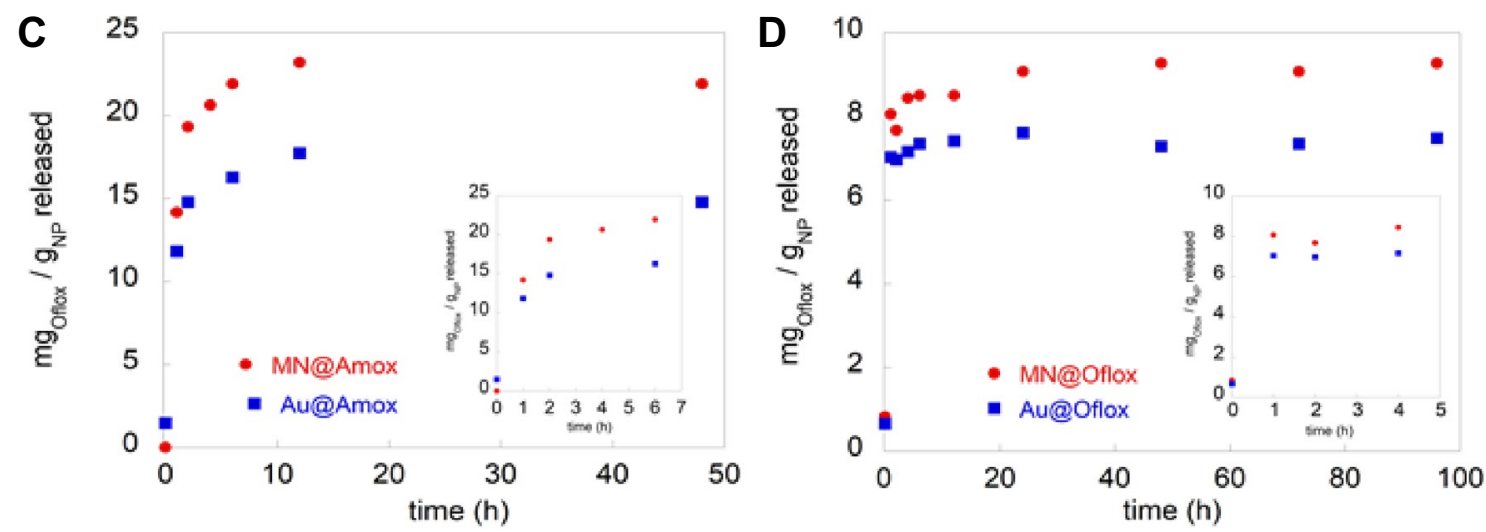

Fig. 3 a Absorption spectra of free antibiotics at approx. 10-5 M. b Chemical structure of both amoxicillin and ofloxacin, and corresponding Loading Capacities (LC) of MNs and Au@MNs systems towards the same antibiotics. c Amoxicillin release profiles from

MNs and Au@MNs, in DMSO at $37{ }^{\circ} \mathrm{C}$, for 5 days-inset: first $6 \mathrm{~h}$ of release. $\mathbf{d}$ Ofloxacin release profiles from MNs and Au@MNs, in DMSO at $37^{\circ} \mathrm{C}$, for 5 days-inset: first $4 \mathrm{~h}$ of release

From the results displayed in Table 5, it is evident that most strains have a high susceptibility to ofloxacin, with all systems showing significant growth inhibition zones after incubations. This is in accordance with the information detailed in previous reports $[52,53]$, as well as ATCC and BacDive database [24-31,54], where no ofloxacin resistance is indicated for any of the studied strains.

Regarding amoxicillin, the methicillin-susceptible $S$. aureus strain exhibited susceptibility to all formulations (i.e. free antibiotics and amoxicilin-loaded NPs), confirming not only the presence of the antibiotic in the nanosystems, but also its effective delivery from the nanoparticles to the bacterial medium. For E. coli, an ihnibition zone of $13 \mathrm{~mm}$ was recorded around the free amoxicillin disk. However, with loaded-MNs and Au@MNs no measurable growth inhibition zones were detected, suggesting an inability of these nanosystems to deliver the necessary amount of antibiotic.

Additionally, and as expected, both MRSA and P. aeruginosa showed strong resistance towards amoxicillin,

as no zones of inhibition were observed for any formulation. Amoxicillin is a $\beta$-lactam antibiotic that binds to transpeptidase domain of penicillin-binding proteins (PBP) preventing peptidoglycan biosynthesis [55]. MRSA methicillin-resistance [3] confers them resistance to other $\beta$-lactam antibiotics, such as oxacillin, penicillin and amoxicillin [56]. This resistance results from expression of $\beta$-lactamases and of an altered form of PBP (encoded by mecA gene) with low affinity to $\beta$-lactam and higher rates of release of the bound drug $[57,58]$ On the other hand, the interaction between the inducible $\beta$-lactamase AmpC and the $P$. aeruginosa resistance nodulation cell division multidrug efflux systems, lists this strain as one towards which amoxicillin is not effective [59].

Despite all registred zones of inhibition for antibioticloaded MNs and Au@MNs systems, none exhibited diameters larger than those obtained for the free antibiotics. This fact may derive from nanoparticles dispersibility issues in the sterile paper disk matrix, that did not allow 
Table 3 Comparison between in-work developed materials and other already published in literature

\begin{tabular}{|c|c|c|c|c|c|c|}
\hline Antibiotic & Supporting material & Material ID & Type of interaction & $\%$ L (\%) & $\mathrm{LC}(\mathrm{mg} / \mathrm{g})$ & Ref. \\
\hline \multirow[t]{30}{*}{ Amoxicillin } & \multirow[t]{4}{*}{ SBA-15 } & SBA-15-x & \multirow[t]{4}{*}{ Adsorption } & - & - & \multirow[t]{4}{*}{ [43] } \\
\hline & & SBA 15-xA & & 19 & - & \\
\hline & & SBA-15-xM & & 25 & - & \\
\hline & & SBA-15-xT & & - & - & \\
\hline & \multirow[t]{3}{*}{ SBA-16 } & SBA-16 & \multirow[t]{3}{*}{ Covalent } & 3.2 & 13 & \multirow[t]{3}{*}{ [44] } \\
\hline & & SBA-16IPD & & 51 & 204 & \\
\hline & & SBA-16IPDB & & 51 & 204 & \\
\hline & \multirow[t]{9}{*}{ MCM-41 } & SiMCM-41 & \multirow[t]{9}{*}{ Adsorption } & 91 & 300 & \multirow[t]{9}{*}[45]{} \\
\hline & & PCIMCM-41 & & 91 & 300 & \\
\hline & & $\mathrm{PNH}_{2} \mathrm{MCM}-41$ & & 91 & 300 & \\
\hline & & CIMCM-41 & & 91 & 300 & \\
\hline & & $\mathrm{CNH}_{2} \mathrm{MCM}-41$ & & 91 & 300 & \\
\hline & & TPCIMCM-41 & & 82 & 270 & \\
\hline & & TPCCIMCM-41 & & 89 & 290 & \\
\hline & & $\mathrm{TPNH}_{2} \mathrm{MCM}-41$ & & 89 & 290 & \\
\hline & & $\mathrm{TCNH}_{2} \mathrm{MCM}-41$ & & 91 & 300 & \\
\hline & MCM-41 & $\mathrm{Fe}_{3} \mathrm{O}_{4} / \mathrm{SiO}_{2} / \mathrm{CTAB}-\mathrm{SiO}_{2}$ & Adsorption & - & 363 & {$[46]$} \\
\hline & \multirow[t]{11}{*}{ MCM-41 } & Pure MCM-41 & \multirow[t]{11}{*}{ Adsorption } & - & 8 & \multirow[t]{11}{*}{ [47] } \\
\hline & & $\mathrm{Si}_{\text {Micro }}$ & & - & 1 & \\
\hline & & $\mathrm{Si}_{\text {Micro }} / 20 \mathrm{Fe} 150$ & & - & 3 & \\
\hline & & $5 F e 150$ & & - & 15 & \\
\hline & & $10 F e 150$ & & - & 20 & \\
\hline & & 20Fe150 & & - & 25 & \\
\hline & & $50 F e 150$ & & - & 20 & \\
\hline & & $5 F e 200$ & & - & 10 & \\
\hline & & 10Fe200 & & - & 15 & \\
\hline & & $20 \mathrm{Fe} 200$ & & - & 18 & \\
\hline & & $50 F e 200$ & & & 12 & \\
\hline & \multirow[t]{2}{*}{ MCM-41 } & MNs & \multirow[t]{2}{*}{ Adsorption } & 62 & 123 & \multirow[t]{2}{*}{ This work } \\
\hline & & Au@MNs & & 70 & 141 & \\
\hline \multirow[t]{8}{*}{ Ofloxacin } & \multirow[t]{4}{*}{ MCM-41 } & MSNPs & \multirow[t]{4}{*}{ Covalent } & 30 & - & \multirow[t]{4}{*}{ [18] } \\
\hline & & AgMSNPs & & 35 & - & \\
\hline & & (DMSO) & & 84 & - & \\
\hline & & (PBS 7.4) & & & & \\
\hline & \multirow[t]{2}{*}{ MCM-41 } & Si.P $P_{700}$ & \multirow[t]{2}{*}{ Adsorption } & 80 & - & \multirow[t]{2}{*}{ [48] } \\
\hline & & $\mathrm{Si}^{-N P_{8}}$ & & 67 & - & \\
\hline & \multirow[t]{2}{*}{ MCM-41 } & MNs & \multirow[t]{2}{*}{ Adsorption } & 31 & 62 & \multirow[t]{2}{*}{ This work } \\
\hline & & Au@MNs & & 35 & 42 & \\
\hline
\end{tabular}

Table 4 Semi-empirical Korsmeyer-Peppas diffusion model parameters upon fitting to experimental amoxicillin and ofloxacin release data

\begin{tabular}{llll}
\hline NP sample & $\mathrm{R}^{2}$ & $n$ & $k\left(t^{-n}\right)$ \\
\hline Amox@MNs & 0.9227 & 0.19 & 0.705 \\
Amox@Au@MNs & 0.9983 & 0.11 & 0.636 \\
Oflox@MNs & 0.9987 & 0.11 & 0.794 \\
Oflox@Au@MNs & 0.9989 & 0.13 & 0.847 \\
\hline
\end{tabular}

for a total dispersion and transport of the antibiotics to bacterial media.

Broth microdilution assays were used to overcome dispersion issues, with each formulation (i.e. free antibiotics, MNs, Au@MNs, Amox@MNs, Amox@Au@MNs, Oflox@ MNs and Oflox@Au@MNs) being resuspended in DMSO to attain good dispersibility and homogeneity. This method allows not only for direct contact between nanoparticles and bacteria but also for greater sensibility. A gradient of concentrations for each formulation, ranging between ca. 
Table 5 Summarising table with all growth inhibition zones' average diameters

\begin{tabular}{|c|c|c|c|c|c|}
\hline \multirow[t]{2}{*}{ NP sample } & \multirow[t]{2}{*}[]{$_{\text {Drug }}(\mathrm{ug} /$ disk) } & \multirow{2}{*}{$\begin{array}{l}\text { Escherichia coli } \\
\bar{d} \text { Inhibition zone }(\mathrm{mm})\end{array}$} & \multirow{2}{*}{$\begin{array}{l}\text { Staphylococcus aureus } \\
\bar{d} \text { Inhibition zone (mm) }\end{array}$} & \multirow{2}{*}{$\begin{array}{l}\text { Methicillin- } \\
\text { resistant } S \text {. } \\
\text { aureus } \\
\bar{d} \text { Inhibition } \\
\text { zone }(\mathrm{mm})\end{array}$} & \multirow{2}{*}{$\begin{array}{l}\text { Pseudomonas aeruginosa } \\
\bar{d} \text { Inhibition zone (mm) }\end{array}$} \\
\hline & & & & & \\
\hline MNs & - & 0 & 0 & 0 & 0 \\
\hline Au@MNs & - & 0 & 7 & 0 & 7 \\
\hline Free Amox & 10.0 & 13 & 45 & 7 & 0 \\
\hline Amox@MNs & 9.8 & 0 & 19 & 0 & 0 \\
\hline Amox@Au@MNs & 11.3 & 0 & 15 & 0 & 0 \\
\hline Free Oflox & 10.0 & 38 & 31 & 32 & 25 \\
\hline Oflox@MNs & 4.4 & 20 & 19 & 17 & 9 \\
\hline Oflox@Au@MNs & 3.3 & 17 & 17 & 14 & 8 \\
\hline DMSO & - & 0 & 0 & 0 & 0 \\
\hline
\end{tabular}

Measured lengths represent the obtained means \pm an associated absolute error of $0.5 \mathrm{~mm}$

10-0.006 $\mu \mathrm{g}_{\text {Antibiotic }} / \mathrm{mL}\left(765-1 \mu \mathrm{g}_{\mathrm{NPs}} / \mathrm{mL}\right)$, was tested to assess both MIC and MBC by absorbance spectroscopic techniques, against E. coli ATCC $8739^{\text {TM }}$, the susceptible $S$. aureus ATCC $6538^{\mathrm{TM}}$, the resistant MRSA ATCC $33591^{\mathrm{TM}}$ and $P$. aeruginosa ATCC $9027^{\mathrm{TM}}$. MIC and MBC validation was attained by plating on TSA plates.

No antibacterial activity was registred with MNs, Au@ MNs and DMSO, that served as controls along the whole experiment. It should be noted that antibiotic concentration is variable, depending on each nanoparticle loading capacity (see Sect. 3.2. Antibiotics Loading and Release studies). Free antibiotics were also tested within a 95-0.015 $\mu \mathrm{g}_{\text {Antibiotic }} / \mathrm{mL}$ concentration range and used as standards (Table 6).

Overall, amoxicillin-loaded systems followed a similar tendency to that observed in disk diffusion assay, having a more effective activity against the susceptible $S$. aureus strain, than for other bacteria.Amox@MNs and Amox@ Au@MNs MICs towards S. aureus matched their own MBCs, that were confirmed for concentrations of $1 \mu \mathrm{g}_{\mathrm{Amox}} / \mathrm{mL}$
Table 6 Minimum inhibitory concentration (MIC) and minimum bactericidal concentration (MBC) of DMSO, MNs, Au@MNs and the free antibiotics towards the selected bacterial strains

\begin{tabular}{llll}
\hline Formulation description & Strain & MIC $(\mu \mathrm{g} / \mathrm{mL})$ & MBC $(\mu \mathrm{g} / \mathrm{mL})$ \\
& & Antibiotic (NP) & Antibiotic (NP) \\
\hline DMSO & E. coli ATCC 8739 & N/D & N/D \\
& S. aureus ATCC 6538 & N/D & N/D \\
& MRSA ATCC 33591 & N/D & N/D \\
& P. aeruginosa ATCC 9027 & N/D & N/D \\
E. coli ATCC 8739 & N/D & N/D \\
MNs & S. aureus ATCC 6538 & N/D & N/D \\
& MRSA ATCC 33591 & N/D & N/D \\
& P. aeruginosa ATCC 9027 & N/D & N/D \\
Au@MNs & E. coli ATCC 8739 & N/D & N/D \\
& S. aureus ATCC 6538 & N/D & N/D \\
& MRSA ATCC 33591 & N/D & N/D \\
P. aeruginosa ATCC 9027 & N/D & N/D \\
Free amoxicilin & S. aureus ATCC 6538 & $5(-)$ & $5(-)$ \\
& MRSA ATCC 33591 & $0.015(-)$ & $0.07(-)$ \\
& P. aeruginosa ATCC 9027 & N/D & N/D \\
& E. coli ATCC 8739 & $0.03(-)$ & N/D \\
S. aureus ATCC 6538 & $0.15(-)$ & $0.03(-)$ \\
MRSA ATCC 33591 & $0.3(-)$ & $0.3(-)$ \\
& P. aeruginosa ATCC 9027 & $0.6(-)$ & $0.6(-)$ \\
& & & $0.6(-)$ \\
\hline
\end{tabular}


$\left(80 \mu \mathrm{g}_{\mathrm{NPs}} / \mathrm{mL}\right)$ and $3 \mu \mathrm{g}_{\mathrm{Amox}} / \mathrm{mL}\left(360 \mu \mathrm{g}_{\mathrm{NPs}} / \mathrm{mL}\right)$, respectively. However, when compared to the obtained viability of the free amoxicillin formulation (Table 6), which led to inhibition at $0.015 \mu \mathrm{g}_{\text {Amox }} / \mathrm{mL}$ and death at $0.07 \mu \mathrm{g}_{\text {Amox }} /$ $\mathrm{mL}$, no significant beneficial role can be assigned to the antibiotic decorated nanoparticles.

Within the range of tested concentrations, amoxicillinnanosystems were only able to inhibit $E$. coli and $P$. aeruginosa growth. All assayed concentrations of Amox@ MNs and Amox@Au@MNs failed to reduce both bacteria viabilities by $99 \%$, pointing to MBCs at values $>765 \mu g_{\mathrm{NPs}} /$ $\mathrm{mL}$. The MIC of Amox@MNs, towards E. coli, was determined for a concentration of $10 \mu \mathrm{g}_{\mathrm{Amox}} / \mathrm{mL}\left(765 \mu \mathrm{g}_{\mathrm{NPs}} / \mathrm{mL}\right)$, whereas no MIC was registred for Amox@Au@MNs (MBC and $\mathrm{MIC}>765 \mu \mathrm{g}_{\mathrm{NPS}} / \mathrm{mL}$ ). Again, when compared to those obtained for the free antibiotic (Table 6) no beneficial role is evident. Regarding $P$. aeruginosa, whilst free amoxicillin only had a MIC at $95 \mu \mathrm{g}_{\text {Amox }} / \mathrm{mL}$, Amox@MNs and Amox@ Au@MNs displayed MICs at lower antibiotic concentrations of $10 \mu \mathrm{g}_{\mathrm{Amox}} / \mathrm{mL}\left(765 \mu \mathrm{g}_{\mathrm{NPs}} / \mathrm{mL}\right)$ and $5 \mu \mathrm{g}_{\mathrm{Amox}} / \mathrm{mL}$ $\left(765 \mu \mathrm{g}_{\mathrm{NPs}} / \mathrm{mL}\right)$, respectively. This result gives our nanosystems a beneficial role in the reduction of prescribed antibiotics, with Amox@MNs and Amox@Au@MNs allowing for a 10 -fold and a 20 -fold reduction, respectively, while maintaining its bacteriostatic activity.

Concerning MRSA, concentrations up to $95 \mu \mathrm{gAmox} /$ $\mathrm{mL}$ of free amoxicillin failled to reduce bacteria viabilities by $50 \%$ (MIC and MBC $>95 \mu \mathrm{g}_{\text {Amox }} / \mathrm{mL}$ ) (Table 6). However, prominent bacteriostatic and bactericidal activity was observed for Amox@MNs that exhibited a MIC of $5 \mu g_{\text {Amox }}$ / $\mathrm{mL}$ (i.e. for $360 \mu \mathrm{g}_{\mathrm{NPs}} / \mathrm{mL}$ ) and a $\mathrm{MBC}$ of $10 \mu \mathrm{g}_{\mathrm{Amox}} / \mathrm{mL}$ $\left(765 \mu \mathrm{g}_{\mathrm{NP}} / \mathrm{mL}\right)$. Thus, leading to not only an higher than 20 -fold decrease in needed antibiotic, but also allowing a circumvention of the already existing resistance.Amox@ Au@MNs, however, showed no MIC and MBC within the tested concentration range. All amoxicillin-based formulation results are sumarised in Table 7.

As observed with free ofloxacin, both ofloxacin nanosystems showed strong effectiveness against all bacterial strains, for most tested concentrations. In general,
Oflox@MNs performance was more stressed than that of its Au-based counterpart, being in line with the above mentioned release profiles of ofloxacin-decorated nanoparticles,where Oflox@MNs showed higher appetency to dispense the antibiotic than Oflox@Au@MNs.

The determined MIC and MBC of Oflox@MNs towards E. coli were both of $0.03 \mu \mathrm{g}_{\mathrm{Oflox}} / \mathrm{mL}\left(4 \mu \mathrm{g}_{\mathrm{NPs}} / \mathrm{mL}\right)$, and identical to those obtained for free ofloxacin (Table 6). Oflox@Au@MNs however, were able to reduce the MIC by half, inducing a $50 \%$ reduction in bacteria viability at $0.015 \mu \mathrm{g}_{\text {oflox }} / \mathrm{mL}\left(4 \mu \mathrm{g}_{\mathrm{NPs}} / \mathrm{mL}\right)$. A similar tendency was observed towards the susceptible $S$. aureus strain, with Oflox@MNs having a MIC (i.e. $0.15 \mu \mathrm{g}_{\text {oflox }} / \mathrm{mL}$ for $20 \mu \mathrm{g}_{\mathrm{NPs}} / \mathrm{mL}$ ) and a MBC (i.e. $0.3 \mu \mathrm{g}_{\mathrm{oflox}} / \mathrm{mL}$ for $40 \mu \mathrm{g}_{\mathrm{NPs}} /$ $\mathrm{mL}$ ) equal to those of the free antibiotic. The presence of Au cores played no beneficial role, leading instead to an increase of the MBC to $0.6 \mu \mathrm{g}_{\mathrm{Oflox}} / \mathrm{mL}\left(170 \mu \mathrm{g}_{\mathrm{NP}} /\right.$ $\mathrm{mL}$ ). Regarding MRSA, whilst Oflox@Au@MNs were capable of decreasing the MIC to half of that obtained for free ofloxacin (i.e. $0.15 \mu \mathrm{g}_{\mathrm{Oflox}} / \mathrm{mL}$ for $40 \mu \mathrm{g}_{\mathrm{NPs}} / \mathrm{mL}$ ), only Oflox@MNs were able to reduce in half the MBC to $0.3 \mu \mathrm{g}_{\text {oflox }} / \mathrm{mL}\left(40 \mu \mathrm{g}_{\mathrm{NP}} / \mathrm{mL}\right)$. Lastly, both Oflox@MNs and Oflox@Au@MNs MBCs showed no significant differences towards $P$. aeruginosa, when compared to that of the free antibiotic. The two formulations were able to induce a 2 -fold reduction in the MIC, to concentrations of $0.3 \mu \mathrm{g}_{\mathrm{Oflox}} / \mathrm{mL}\left(40 \mu \mathrm{g}_{\mathrm{NP}} / \mathrm{mL}\right.$ and $80 \mu \mathrm{g}_{\mathrm{NP}} / \mathrm{mL}$ for Oflox@ MNs and Oflox@Au@MNs, respectively). A compilation of all ofloxacin-based formulation is displayed in Table 8.

The significant decrease in needed antibiotic is hypothesised to be the result of a mixed effect between the already reported protective role of the mesoporous structures over loaded drugs and antibiotics $[10,60]$, and the attaching and stressing power of MNs shells onto the surface of bacteria $[61,62]$.

It should be noted that, tested concentrations (of NPs and antibiotics) are three to four orders of magnitude lower than those tested in a sterile paper disk, highlightning again the importance of direct contact between nanoparticles and bacteria.
Table 7 Minimum inhibitory concentration (MIC) and minimum bactericidal concentration (MBC) for all amoxicillin-based tested formulations, against selected bacterial strains

\begin{tabular}{llll}
\hline Formulation description & Strain & $\begin{array}{l}\text { MIC }(\mu \mathrm{g} / \mathrm{mL}) \\
\text { Antibiotic (NP) }\end{array}$ & $\begin{array}{l}\mathrm{MBC}(\mu \mathrm{g} / \mathrm{mL}) \\
\text { Antibiotic (NP) }\end{array}$ \\
\hline Amox@MNs & E. coli ATCC 8739 & $10(765)$ & $\mathrm{N} / \mathrm{D}$ \\
Amox c.a. 122.75 mg/g & S. aureus ATCC 6538 & $1(80)$ & $1(80)$ \\
& MRSA ATCC 33591 & $5(360)$ & $10(765)$ \\
& P. aeruginosa ATCC 9027 & $10(765)$ & $\mathrm{N} / \mathrm{D}$ \\
Amox@Au@MNs & E. coli ATCC 8739 & $\mathrm{N} / \mathrm{D}$ & $\mathrm{N} / \mathrm{D}$ \\
Amox c.a. 140.85 mg/g & S. aureus ATCC 6538 & $3(360)$ & $5(765)$ \\
& MRSA ATCC 33591 & N/D & N/D \\
& P. aeruginosa ATCC 9027 & $5(765)$ & N/D \\
\hline
\end{tabular}


Table 8 Minimum inhibitory concentration (MIC) and minimum bactericidal concentration (MBC) for all ofloxacin-based tested formulations, against selected bacterial strains

\begin{tabular}{llcc}
\hline Formulation description & Strain & $\begin{array}{l}\text { MIC }(\mu \mathrm{g} / \mathrm{mL}) \\
\text { Antibiotic }(\mathrm{NP})\end{array}$ & $\begin{array}{l}\mathrm{MBC}(\mu \mathrm{g} / \mathrm{mL}) \\
\text { Antibiotic (NP) }\end{array}$ \\
\hline Oflox@MNs & E. coli ATCC 8739 & $0.03(4)$ & $0.03(4)$ \\
Oflox c.a. 62.32 mg/g & S. aureus ATCC 6538 & $0.15(20)$ & $0.3(40)$ \\
& MRSA ATCC 33591 & $0.3(40)$ & $0.3(40)$ \\
& P. aeruginosa ATCC 9027 & $0.3(40)$ & $0.6(80)$ \\
Oflox@Au@MNs & E. coli ATCC 8739 & $0.015(4)$ & $0.03(10)$ \\
Oflox c.a. 42.18 mg/g & S. aureus ATCC 6538 & $0.15(40)$ & $0.6(170)$ \\
& MRSA ATCC 33591 & $0.15(40)$ & $0.6(170)$ \\
& P. aeruginosa ATCC 9027 & $0.3(80)$ & $0.6(170)$ \\
\hline
\end{tabular}

Silica-based nanoparticles that have been reported to efficiently bind to both Gram-negative and Grampositive bacteria, as all herein tested bacteria [63], and have already been reported to change surface roughness and stability, while inducing membrane stress and membrane disruption (namely by the silanol groups that have appetency for phospholipid membrane destruction) [64]. Thus, an increase in membrane permeabilization could expedite antibiotic access and, consequentely, their action inside bacterial cells [65].

Particularly, in what concerns $\beta$-lactam antibiotics, high antibiotic concentrations could be dispensed in bacterial cells by nanoparticle/antibiotic combinations, allowing the antibiotic to act before being degraded by bacterial $\beta$-lactamases $[66,67]$. Additionally, antibiotic nanosystems could inhibit the transmembrane pump that catalyses drug efflux from $P$. aeruginosa cells [67].

Moreover, the induction of MRSA resistance reversion by Amox@MNs could be related to MNs perturbations in cell envelope upon interaction with the bacteria. As hypothesised by Kong et al. [68], the resulting perturbations in cell envelope could affect the expression of resistance-responsible genes, by disrupting the activity of sensor-inducer proteins located in cell membrane, which are responsible for the expression of resistance proteins.

Briefly, the herein synthesised formulations had a considerable beneficial role on the effective delivery of amoxicillin to the selected strains; namely, against the resistant $S$. aureus mutant, MRSA, and the well-known $\beta$-lactam resistant $P$. aeruginosas. Among its more promising results, are the significant reduction of amoxicillin in future prescriptions, reducing the possibility of development of resistance, and Amox@MNs' surprising circumvention of MRSA resistance. Ofloxacin loaded nanoparticles did not show as outstanding performances as those of their amoxicillin-loaded counterparts, being only able to slightly reduce ofloxacin amounts for both MIC and MBC.

\section{Conclusions}

To summarise, nanocarriers comprising of core-shell gold-silica based mesoporous nanoparticles (Au@MNs) and silica mesoporous nanoparticles (MNs) were successfully synthesised and fully characterised. Both nanocarriers revealed a spherical shape and high porosity with surface areas of $1028.13 \mathrm{~m}^{2} / \mathrm{g}$ and $940.22 \mathrm{~m}^{2} / \mathrm{g}$ for Au@MNs and $\mathrm{MNs}$, respectively. The loading ability of these nanosystems was evaluated towards amoxicillin and ofloxacin antibiotics, where high encapsulation yields of $62 \%$ (MNs) and 70\% (Au@MNs) were achieved for amoxicillin. Amox@ MNs,Amox@Au@MNs, Oflox@MNs and Oflox@Au@MNs nanoformulations were tested against $S$. aureus, methicillin-resistant S. aureus (MRSA), E. coli and P. aeruginosa in sterile paper disks and by broth microdilution assays. The best results were achieved by broth microdilutions assays, since this method allows a direct contact between nanoparticles and bacteria. Which was confirmed as crucial variable. Within the range of tested concentrations, amoxicillin-nanosystems were able to inhibit $E$. coli and $P$. aeruginosa growth. From the obtained results, it is clear their significant and benefical role, by promoting a 10 -fold (Amox@MNs) and a 20-fold (Amox@Au@MNs) reduction of needed amoxicillin to inhibed $P$. aeruginosa. Regarding MRSA, not only a 20-fold decrease in amoxicillin MIC was obtanined for Amox@MNs, but also a full circumvenction of the resistance was possible at a $M B C$ of $5 \mu_{A m o x} g / m L$. Ofloxacin loaded nanoparticles were also able to reduce ofloxacin amounts in both MIC and MBC, although less significantly. The above obtained results, aligned with the straighforwardness and cheapness of the reported base materials, may place these novel formulation as a possible and determining therapeutic tools to tackle AMR and its development.

Acknowledgements GM and EO thank the financial support by the Associate Laboratory Research Unit for Green Chemistry-Clean Processes and Technologies-LAQV which is financed by national 
funds from FCT/MEC (UID/QUI/50006/2013) and co-financed by the ERDF under the PT2020 Partnership Agreement (POCI-01-0145FEDER-007265), as well as the Scientific Society PROTEOMASS (Portugal) for funding support (General Funding Grant). G.M thanks to FCT/MEC (Portugal) for his doctoral Grant PD/BD/142865/2018. E.O thanks FCT/MEC (Portugal) for the individual contract, CEECIND/00648/2017. MPD acknowledge the financial support by FCTFundação para a Ciência e Tecnologia within the R\&D Units Project Scope: UIDB/04077/2020.

\section{Compliance with ethical standards}

Conflict of interest The authors declare no conflict of interest.

\section{References}

1. Dodds DR (2017) Antibiotic resistance: a current epilogue. Biochem Pharmacol 134:139-146. https://doi.org/10.1016/j. bcp.2016.12.005

2. MacGowan A, Macnaughton E (2017) Antibiotic resistance. Medicine 45:622-628. https://doi.org/10.1016/j.mpmed.2017.07.006

3. Martínez-Carmona M, Gun'ko Y, Vallet-Regí M (2018) Mesoporous silica materials as drug delivery: "The Nightmare" of bacterial infection. Pharmaceutics 10:279. https://doi. org/10.3390/pharmaceutics10040279

4. Beyth N, Houri-Haddad Y, Domb A, Khan W, Hazan R (2015) Alternative antimicrobial approach: nano-antimicrobial materials. Evid Based Complement Altern Med 2015:1-16. https:// doi.org/10.1155/2015/246012

5. Weir E, Lawlor A, Whelan A, Regan F (2008) The use of nanoparticles in anti-microbial materials and their characterization. The Analyst 133:835. https://doi.org/10.1039/b715532h

6. Li X, Robinson SM, Gupta A, Saha K, Jiang Z, Moyano DF, Sahar A, Riley MA, Rotello VM (2014) Functional gold nanoparticles as potent antimicrobial agents against multi-drug-resistant bacteria. ACS Nano 8:10682-10686. https://doi.org/10.1021/nn504 2625

7. Pal S, Tak YK, Song JM (2007) Does the antibacterial activity of silver nanoparticles depend on the shape of the nanoparticle? A study of the gram-negative bacterium Escherichia coli. Appl Environ Microbiol 73:1712-1720. https://doi.org/10.1128/ AEM.02218-06

8. Sirelkhatim A, Mahmud S, Seeni A, Kaus NHM, Ann LC, Bakhori SKM, Hasan H, Mohamad D (2015) Review on zinc oxide nanoparticles: antibacterial activity and toxicity mechanism. Nano-Micro Lett 7:219-242. https://doi.org/10.1007/s4082 0-015-0040-x

9. Usman MS, El Zowalaty ME, Shameli K, Zainuddin N, Salama M, Ibrahim NA (2013) Synthesis, characterization, and antimicrobial properties of copper nanoparticles. Int J Nanomed 8:4467-4479. https://doi.org/10.2147/IJN.S50837

10. Zaidi S, Misba L, Khan AU (2017) Nano-therapeutics: a revolution in infection control in post antibiotic era. Nanomed Nanotechnol Biol Med 13:2281-2301. https://doi.org/10.1016/j. nano.2017.06.015

11. Şen Karaman D, Manner S, Rosenholm JM (2018) Mesoporous silica nanoparticles as diagnostic and therapeutic tools: How can they combat bacterial infection? Therap Deliv 9(4):241-244. https://doi.org/10.4155/tde-2017-0111

12. Xu C, Cao Y, Lei C, Li Z, Kumeria T, Meka AK, Xu J, Liu J, Yan C, Luo L, Khademhosseini A, Popat A, He Y, Ye Q (2020) Polymermesoporous silica nanoparticle core-shell nanofibers as a dual-drug-delivery system for guided tissue regeneration. ACS Appl Nano Mater 3(2):1457-1467. https://doi.org/10.1021/ acsanm.9b02298

13. Raza A, Sime FB, Cabot PJ, Maqbool F, Roberts JA, Falconer JR (2019) Solid nanoparticles for oral antimicrobial drug delivery: a review. Drug Discov Today 24(3):858-866. https://doi. org/10.1016/j.drudis.2019.01.004

14. Zhu Y, Xu J, Wang Y, Chen C, Gu H, Chai Y, Wang Y (2020) Silver nanoparticles-decorated and mesoporous silica coated single-walled carbon nanotubes with an enhanced antibacterial activity for killing drug-resistant bacteria. Nano Res 13(2):389-400. https://doi.org/10.1007/s12274-020-2621-3

15. Liu J, Li S, Fang Y, Zhu Z (2019) Boosting antibacterial activity with mesoporous silica nanoparticles supported silver nanoclusters. J Colloid Interface Sci 555:470-479. https://doi. org/10.1016/j.jcis.2019.08.009

16. Liong M, France B, Bradley KA, Zink JI (2009) Antimicrobial activity of silver nanocrystals encapsulated in mesoporous silica nanoparticles. Adv Mater 21(17):1684-1689. https://doi. org/10.1002/adma.200802646

17. Lu MM, Wang QJ, Chang ZM, Wang Z, Zheng X, Shao D, Dong WF, Zhou YM (2017) Synergistic bactericidal activity of chlorhexidine-loaded, silver-decorated mesoporous silica nanoparticles. Int J Nanomed 12:3577-3589. https://doi. org/10.2147/IJN.S133846

18. Nuti S, Fernández-Lodeiro J, Del Secco B, Rampazzo E, Rodríguez-González B, Capelo JL, Silva V, Igrejas G, Poeta P, Torres C, Zaccheroni N, Prodi L, Oliveira E, Lodeiro C (2018) Engineered nanostructured materials for ofloxacin delivery. Front Chem. https://doi.org/10.3389/fchem.2018.00554

19. Tahmasbi L, Sedaghat T, Motamedi H, Kooti M (2018) Mesoporous silica nanoparticles supported copper(II) and nickel(II) Schiff base complexes: synthesis, characterization, antibacterial activity and enzyme immobilization. J Solid State Chem 258:517-525. https://doi.org/10.1016/j.jssc.2017.11.015

20. Turkevich J, Stevenson PC, Hillier J (1951) A study of the nucleation and growth processes in the synthesis of colloidal gold. Discuss Faraday Soc 11:55. https://doi.org/10.1039/df951 1100055

21. Kimling J, Maier M, Okenve B, Kotaidis V, Ballot $H$, Plech A (2006) Turkevich method for gold nanoparticle synthesis revisited. J Phys Chem B 110:15700-15707. https://doi. org/10.1021/jp061667w

22. Kobayashi Y, Katakami H, Mine E, Nagao D, Konno M, Liz-Marzán LM (2005) Silica coating of silver nanoparticles using a modified Stober method. J Colloid Interface Sci 283(2):392396. https://doi.org/10.1016/j.jcis.2004.08.184

23. Siepmann J (2001) Modeling of drug release from delivery systems based on hydroxypropyl methylcellulose (HPMC). Adv Drug Deliv Rev 48:139-157. https://doi.org/10.1016/S0169 $-409 \times(01) 00112-0$

24. Escherichia coli (2019) Leibniz-Institut DSMZ-Deutsche Sammlung von Mikroorganismen und Zellkulturen $\mathrm{GmbH}$. Accessed 11 Feb 2020

25. Product Sheet Escherichia coli $\left(\right.$ ATCC $^{\circ} 8739^{\text {TM }}$ ) (2019) https:// www.lgcstandards-atcc.org/products/all/8739.aspx\#docum entation. Accessed 11 Feb 2020

26. Pseudomonas aeruginosa (2019) Leibniz-Institut DSMZDeutsche Sammlung von Mikroorganismen und Zellkulturen $\mathrm{GmbH}$. Accessed 11 Feb 2020

27. Product Sheet Pseudomonas aeruginosa (ATCC ${ }^{\circ} 9027^{\mathrm{TM}}$ ) (2019) https://www.lgcstandards-atcc.org/products/all/9027. aspx\#documentation. Accessed 11 Feb 2020

28. Staphylococcus aureus subsp. aureus (2019) Leibniz-Institut DSMZ-Deutsche Sammlung von Mikroorganismen und Zellkulturen GmbH. Accessed 11 Feb 2020 
29. Product Sheet Staphylococcus aureus subsp. aureus (ATCC ${ }^{\circ}$ $6538^{\mathrm{TM}}$ ) (2019) https://www.lgcstandards-atcc.org/products/ all/6538.aspx\#documentation. Accessed 11 Feb 2020

30. Staphylococcus aureus (2019) Leibniz-Institut DSMZ-Deutsche Sammlung von Mikroorganismen und Zellkulturen $\mathrm{GmbH}$. Accessed 11 Feb 2020

31. Product Sheet Staphylococcus aureus subsp. aureus (ATCC ${ }^{\circ}$ $33591^{\mathrm{TM}}$ ) (2019) https://www.lgcstandards-atcc.org/products/ all/33591.aspx\#documentation. Accessed 11 Feb 2020

32. Bauer AW, Kirby WMM, Sherris JC, Turck M (1966) Antibiotic susceptibility testing by a standardized single disk method. Am J Clin Pathol 45:493-496. https://doi.org/10.1093/ ajcp/45.4_ts.493

33. Giannousi K, Pantazaki A, Dendrinou-Samara C (2017) Copperbased nanoparticles as antimicrobials. Nanostructures for antimicrobial therapy. Elsevier, Amsterdam. https://doi.org/10.1016/ B978-0-323-46152-8.00023-8

34. Doyen M, Bartik K, Bruylants G (2013) UV-Vis and NMR study of the formation of gold nanoparticles by citrate reduction: observation of gold-citrate aggregates. J Colloid Interface Sci 399:1-5. https://doi.org/10.1016/j.jcis.2013.02.040

35. Oliveira E, Núñez C, Santos HM, Fernández-Lodeiro J, FernándezLodeiro A, Capelo JL, Lodeiro C (2015) Revisiting the use of gold and silver functionalised nanoparticles as colorimetric and fluorometric chemosensors for metal ions. Sens Actuators B Chem 212:297-328. https://doi.org/10.1016/j.snb.2015.02.026

36. Oliveira E, Santos HM, Jorge S, Rodríguez-González B, Novio F, Lorenzo J, Ruiz-Molina D, Capelo JL, Lodeiro C (2019) Sustainable synthesis of luminescent $\mathrm{CdTe}$ quantum dots coated with modified silica mesoporous nanoparticles: towards new protein scavengers and smart drug delivery carriers. Dyes Pigm 161:360-369. https://doi.org/10.1016/j.dyepig.2018.09.047

37. Marcelo G, Ariana-Machado J, Enea M, Carmo H, RodríguezGonzález B, Luis Capelo J, Lodeiro C, Oliveira E (2018) Toxicological evaluation of luminescent silica nanoparticles as new drug nanocarriers in different cancer cell lines. Materials. https ://doi.org/10.3390/ma11081310

38. Kruk M, Jaroniec M, Kim JM, Ryoo R (1999) Characterization of highly ordered MCM-41 silicas using X-ray diffraction and nitrogen adsorption. Langmuir 15(16):5279-5284. https://doi. org/10.1021/la990179v

39. Li Q, Brown SE, Broadbelt LJ, Zheng J-G, Wu NQ (2003) Synthesis and characterization of $\mathrm{MCM}$-41-supported $\mathrm{Ba}_{2} \mathrm{SiO}_{4}$ base catalyst. Microporous Mesoporous Mater 59(2):105-111. https://doi. org/10.1016/S1387-1811(03)00290-7

40. Souza MJB, Araujo AS, Pedrosa AMG, Marinkovic BA, Jardim PM, Morgado E (2006) Textural features of highly ordered AlMCM-41 molecular sieve studied by X-ray diffraction, nitrogen adsorption and transmission electron microscopy. Mater Lett 60(21):2682-2685. https://doi.org/10.1016/j.matlet.2006.01.066

41. Biao L, Tan S, Meng Q, Gao J, Zhang X, Liu Z, Fu Y (2018) Green synthesis, characterization and application of proanthocyanidins-functionalized gold nanoparticles. Nanomaterials. https:// doi.org/10.3390/nano8010053

42. Zhu K, Hu J, Richards R (2005) Aerobic oxidation of cyclohexane by gold nanoparticles immobilized upon mesoporous silica. Catal Lett 100(3):195-199. https://doi.org/10.1007/s1056 2-004-3454-5

43. Sevimli F, Yılmaz A (2012) Surface functionalization of SBA-15 particles for amoxicillin delivery. Microporous Mesoporous Mater 158:281-291. https://doi.org/10.1016/j.micro meso.2012.02.037

44. Airoldi C, Oliveira VV (2014) Hydrophobic contribution to amoxicillin release associated with organofunctionalized mesoporous SBA-16 carriers. Mater Res Bull 59:214-222. https ://doi.org/10.1016/j.materresbull.2014.06.031
45. Li Z, Su K, Cheng B, Deng Y (2010) Organically modified MCMtype material preparation and its usage in controlled amoxicillin delivery. J Colloid Interface Sci 342(2):607-613. https://doi. org/10.1016/j.jcis.2009.10.073

46. Zandipak R, Sobhanardakani S (2018) Novel mesoporous $\mathrm{Fe}_{3} \mathrm{O}_{4} /$ $\mathrm{SiO}_{2} / \mathrm{CTAB}-\mathrm{SiO}_{2}$ as an effective adsorbent for the removal of amoxicillin and tetracycline from water. Clean Technol Environ Policy 20(4):871-885. https://doi.org/10.1007/s 1009 8-018-1507-5

47. Salviano $A B$, Santos MRD, de Araújo LM, Ardisson JD, Lago RM, Araujo MH (2018) Iron oxide nanoparticles supported on mesoporous MCM-41 for efficient adsorption of hazardous B-lactamic antibiotics. Water Air Soil Pollut 229(3):59. https:// doi.org/10.1007/s11270-017-3652-6

48. Goyne KW, Chorover J, Kubicki JD, Zimmerman AR, Brantley SL (2005) Sorption of the antibiotic ofloxacin to mesoporous and nonporous alumina and silica. J Colloid Interface Sci 283(1):160170. https://doi.org/10.1016/j.jcis.2004.08.150

49. Paarakh MP, Jose PA, Setty CM, Peter GV (2018) Release kinetics-concepts and applications. Int J Pharm Res Technol 8:12

50. Peppas NA, Sahlin JJ (1989) A simple equation for the description of solute release. III. Coupling of diffusion and relaxation. Int J Pharm 57(2):169-172. https://doi.org/10.1016/03785173(89)90306-2

51. Ritger PL, Peppas NA (1987) A simple equation for description of solute release. II. Fickian and anomalous release from swellable devices. J Control Rel 5(1):37-42. https://doi.org/10.1016/01683659(87)90035-6

52. Ham J-S, Lee S-G, Jeong S-G, Oh M-H, Kim D-H, Lee T, Lee B-Y, Yoon SH, Kim H (2010) Powerful usage of phylogenetically diverse Staphylococcus aureus control strains for detecting multidrug resistance genes in transcriptomics studies. Mol Cells 30:71-76. https://doi.org/10.1007/s10059-010-0090-3

53. Hamdad F, Donda F, Lefebvre JF, Laurans G, Biendo M, Thomas D, Canarelli B, Rousseau F, Eb F (2006) Detection of methicillin/ oxacillin resistance and typing in aminoglycoside-susceptible methicillin-resistant and kanamycin-tobramycin-resistant methicillin-susceptible Staphylococcus aureus. Microbial Drug Resist 12:177-185. https://doi.org/10.1089/mdr.2006.12.177

54. Reimer LC, Vetcininova A, Carbasse JS, Söhngen C, Gleim D, Ebeling C, Overmann J (2018) BacDive in 2019: bacterial phenotypic data for high-throughput biodiversity analysis. Nucleic Acids Res 47(D1):D631-D636. https://doi.org/10.1093/nar/gky879

55. Berger-Bächi B, Rohrer S (2002) Factors influencing methicillin resistance in staphylococci. Arch Microbiol 178(3):165-171. https://doi.org/10.1007/s00203-002-0436-0

56. Jones J (2006) Chapter 11-Infectious Diseases. In: Sproat C, Burke G, McGurk M (eds) Essential Human disease for dentists. Churchill Livingstone, Edinburgh, pp 177-194. https://doi. org/10.1016/B978-0-443-10098-7.50014-2

57. Abdelbary MMH, Basset P, Blanc DS, Feil EJ (2017) 24-The evolution and dynamics of methicillin-resistant Staphylococcus aureus. In:Tibayrenc M (ed) Genetics and evolution of infectious diseases, 2nd edn. Elsevier, London, pp 553-572. https://doi. org/10.1016/B978-0-12-799942-5.00024-X

58. Stapleton PD, Taylor PW (2002) Methicillin resistance in Staphylococcus aureus: mechanisms and modulation. Sci Prog 85(Pt 1):57-72

59. Morita $Y$, Tomida J, Kawamura $Y$ (2014) Responses of Pseudomonas aeruginosa to antimicrobials. Front Microbiol 4:422. https://doi.org/10.3389/fmicb.2013.00422

60. Wang Y, Zhao Q, Han N, Bai L, Li J, Liu J, Che E, Hu L, Zhang Q, Jiang T, Wang S (2015) Mesoporous silica nanoparticles in drug delivery and biomedical applications. Nanomed Nanotechnol Biol Med 11:313-327. https://doi.org/10.1016/j. nano.2014.09.014 
61. Song H, Ahmad Nor Y, Yu M, Yang Y, Zhang J, Zhang H, Xu C, Mitter N, Yu C (2016) Silica nanopollens enhance adhesion for long-term bacterial inhibition. J Am Chem Soc 138:6455-6462. https://doi.org/10.1021/jacs.6b00243

62. Wang Y, Nor YA, Song H, Yang Y, Xu C, Yu M, Yu C (2016) Smallsized and large-pore dendritic mesoporous silica nanoparticles enhance antimicrobial enzyme delivery. J Mater Chem B 4:2646-2653. https://doi.org/10.1039/C6TB00053C

63. Siemer S, Westmeier D, Barz M, Eckrich J, Wunsch D, Seckert C, Thyssen C, Schilling O, Hasenberg M, Pang C, Docter D, Knauer SK, Stauber RH, Strieth S (2019) Biomolecule-corona formation confers resistance of bacteria to nanoparticle-induced killing: implications for the design of improved nanoantibiotics. Biomaterials 192:551-559. https://doi.org/10.1016/j.biomateria Is.2018.11.028

64. Capeletti LB, De Oliveira LF, Gonçalves kDa, De Oliveira JFA, Saito Â, Kobarg J, Santos JHZD, Cardoso MB (2014) Tailored silica-antibiotic nanoparticles: overcoming bacterial resistance with low cytotoxicity. Langmuir 30:7456-7464. https://doi.org/10.1021/ la4046435
65. Aelenei P, Rimbu CM, Guguianu E, Dimitriu G, Aprotosoaie AC, Brebu M, Horhogea CE, Miron A (2019) Coriander essential oil and linalool-interactions with antibiotics against gram-positive and gram-negative bacteria. Lett Appl Microbiol 68(2):156164. https://doi.org/10.1111/lam.13100

66. Shaikh S, Nazam N, Rizvi MS, Ahmad K, Baig HM, Lee JE, Choi I (2019) Mechanistic insights into the antimicrobial actions of metallic nanoparticles and their implications for multidrug resistance. Int J Mol Sci. https://doi.org/10.3390/ijms20102468

67. Singh P, Garg A, Pandit S, Mokkapati RSSV, Mijakovic I (2018) Antimicrobial effects of biogenic nanoparticles. Nanomaterials. https://doi.org/10.3390/nano8121009

68. Kong R, Kang O-H, Seo Y-S, Mun S-H, Zhou T, Shin D-W, Kwon $D-Y$ (2016) The inhibition effect of Chlorpromazine against the $\beta$-lactam resistance of MRSA. Asian Pac JTrop Med 9(6):542-546. https://doi.org/10.1016/j.apjtm.2016.04.008

Publisher's Note Springer Nature remains neutral with regard to jurisdictional claims in published maps and institutional affiliations. 